La Revista Panamericana de Salud Pública/Pan American Journal of Public Health se complace en publicar cartas de los lectores dirigidas a estimular el diálogo sobre los diversos aspectos de la salud pública en las Américas, así como a esclarecer, discutir o comentar de manera constructiva las ideas expuestas en la revista. Las cartas deben estar firmadas por el autor y especificar su afiliación profesional y dirección postal. Cuando se trate de comentarios sobre un artículo que requieran contestación del autor, se procurará conseguir esa respuesta con el fin de publicar ambas cartas. La Redacción se reserva el derecho de editar las cartas recibidas y resumirlas para mayor claridad.

The Revista Panamericana de Salud Pública/Pan American Journal of Public Health publishes letters from readers for the purpose of stimulating dialogue on various aspects of public health in the Americas and of constructively clarifying, discussing, and critiquing the ideas expressed throughout its pages. Letters should be signed by the author and include his or her professional affiliation and mailing address. If a commentary on a given article requires a reply from the author, an effort will be made to obtain the reply and to publish both letters. The editorial team reserves the right to edit all letters received and to condense them so as to improve their clarity.

\section{ADVERSE REACTION POTENTIAL OF THREE MEASLES-MUMPS-RUBELLA COMBINATION VACCINES}

In a recent issue of the Revista Panamericana de Salud Pública/Pan American Journal of Public Health, Santos et al. (1) reported meticulous data on adverse reactions attributable to three different measlesmumps-rubella (MMR) combination vaccines. Their findings would certainly guide public health administrators and clinicians all over the world to offer the least-toxic vaccine combinations. Nevertheless, before these data are extrapolated and applied in the field, it would be better if the potency of different combination vaccines in the field were also addressed. Lyophilized lots of measles vaccines have to be constantly maintained at a cold temperature. Reconstituted measles vaccine undergoes a $50 \%$ loss of potency after exposure to $22{ }^{\circ} \mathrm{C}-25{ }^{\circ} \mathrm{C}$ for only 1 hour. Furthermore, its exposure to a temperature above $37{ }^{\circ} \mathrm{C}$ leads to inactivation within 1 hour (2).

Field evaluations of storage facilities and potency of measles vaccines designated for use in the Brazilian Immunization Program have been alarming $(3,4)$. During the early 1990s, measles vaccine titers in $100 \%$ of vaccine samples in public health units in Niterói and São Gonçalo, two municipalities in the state of Rio de Janeiro, were under the minimal recommended potency (3). Four years later, in $55.2 \%$ of the vaccine lots at the respective public health units in Niterói the titers were under the minimum recommended potency (4).
Storage of measles vaccine lots in government and private sector facilities at temperatures higher than the ones stipulated has been documented in both developing and industrialized countries. Several studies, for example, have looked at the case of Nigeria $(5,6)$. In two government-recognized vaccination centers in the city of Ibadan the quality of measles vaccines offered to vaccinees was inadequate. At the Adeyo Maternity Centre in Lagos the vaccine titer was less than $10^{2} 50 \%$ tissue culture infective dose in 5 of the 7 lots examined, and the resultant seroconversion rate was $26 \%$. However, in the Institute of Child Health in Lagos, vaccine titers were low in only 4 of the 16 lots assayed, and $64 \%$ of the vaccine recipients had seroconverted. In the states of Lagos, Osun, and Oyo, vaccine potency was adversely affected at two levels, that of the local government area cold stores and that of the vaccination centers.

Nor is the situation in a highly developed country such as the United States of America perfect at all times. Inadvertent exposures to temperatures outside the ones stipulated were reported with refrigerators in pediatric offices and clinics in the city of Los Angeles, California (7). Other research, in the state of Georgia, found a variety of problems with the refrigerators or freezers used to store vaccines in the offices of private physicians who immunize children (8). The temperature inside the refrigerator exceeded $8{ }^{\circ} \mathrm{C}$ in $22 \%$ of the Georgia offices, and it was above $9{ }^{\circ} \mathrm{C}$ in $4.5 \%$ of them. The refrigerator temperature was lower than $1{ }^{\circ} \mathrm{C}$ in $14.9 \%$ of the refrigera- 
tors. There was no thermometer to monitor the true refrigerator temperature in $6.9 \%$ of the offices.

Irrespective of the individual vaccine components in combined measles-mumps-measles vaccines (1), only robust vaccine lots would offer an efficient armory. Whether they are subcutaneous or aerosol, future MMR vaccines should be designed to resist extended power outages. Power outages such as the ones that the state of California suffered in January 2001 are alarming. Similar episodes are not unlikely elsewhere, and they would be best addressed through the use of stabilized vaccines.

\author{
Subhash C. Arya \\ Nirmala Agarwal \\ Sant Parmanand Hospital \\ 18 Alipore Road \\ Delhi-110054, India \\ E-mail: subhashij@hotmail.com
}

\section{References}

1. Santos BA dos, Ranieri TS, Bercini M, Schermann MT, Famer S, Mohrdieck R. An evaluation of the adverse reaction potential of three measles-mumps-rubella combination vaccines. Rev Panam Salud Publica 2002;12(4):240-246.

2. Australia, National Health and Medical Research Council. The Australian immunization handbook. 6th ed. Canberra: Australian Government Publishing Service; 1997.

3. Oliveira SA, Homma A, Mahul DC, Loureiro ML, CamilloCoura L. Avaliação das condições de estocagem da vacina contra o sarampo nas unidades sanitarias dos municipios de Niterói e São Gonçalo, estado do Rio de Janeiro. Rev Inst Med Trop Sao Paulo 1991;33(4):313-318.

4. Oliveira SA, Loureiro ML, Kiffer CR, Maduro LM. Re-evaluation of the basic procedures involved in the storage of measles vaccine in public health units of the municipality of Niterói, State of Rio de Janeiro, Brazil. Rev Soc Bras Med Trop 1993;26(3):145-149.

5. Onoja AL, Adu FD, Tomori O. Evaluation of measles vaccination programme conducted in two separate health centers. Vaccine 1992;10:49-52.

6. Adu FD, Adedeji AA, Esan JS, Odusanya OG. Live viral vaccine potency: an index for assessing the cold chain system. Public Health 1996;110(6):325-330.

7. Bishai DM, Bhatt S, Miller LT, Hayden GF. Vaccine storage practices in pediatric offices. Pediatrics 1992;89:193-196.

8. Bell KN, Hogue CJR, Manning C, Kendal A. Risk factors for improper vaccine storage and handling in private office providers. Pediatrics 2001;107(6):85-89.

\section{REPLY}

In their letter, Dr. Arya and Dr. Agarwal raise relevant points concerning the importance of the cold chain for the conservation of the measles vaccine, which are also valid for other vaccines. Fundamentally, the efficacy of each vaccine is ensured by its storage at ideal temperatures, from the moment of production until being used in the population $(1,2)$.
In our study (3) the vaccines used were donated by the three laboratories that produced them-Institute Pasteur Merieux, Merck-SharpDohme, and Serum Institute of India-and they were shipped directly to us. All the vaccines were tested by the Brazilian National Institute for Quality Control in Health (Instituto Nacional de Controle de Qualidade em Saúde) before being administered, and their potency was verified. These vaccine strains were not the same as those used by the Brazilian National Immunization Program (Programa Nacional de Imunizações) and mentioned in the letter by Arya and Agarwal.

With respect to the logistics of the study, the storage, handling, and administration of the vaccines were controlled variables. We followed the guidelines recommended by Brazil's National Health Foundation (Fundação Nacional de Saúde), as described in their manual for the cold chain (4). The vaccines were administered immediately after being reconstituted, during the winter, which in southern Brazil is characterized by low temperatures (average $10{ }^{\circ} \mathrm{C}$ ).

It is also important to underscore that in Brazil the last confirmed case of measles occurred in March of 2002 and that it was imported from Japan (5). We do not have any reports of autochthonous cases thanks to the work carried out by the National Immunization Program through its vaccination strategies, which have received worldwide recognition.

Taking these aspects into consideration, we believe that the data concerning the reactogenicity of the three measles-mumps-rubella combination vaccines evaluated in our study are in essence related to the strains that protect against mumps.

\section{Boaventura Antonio dos Santos Hospital de Clínicas de Porto Alegre Rua Ramiro Barcelos, 2350 CEP- 90035-003 \\ Porto Alegre, Rio Grande do Sul, Brazil}

\section{References}

1. Murray-Perrault K, Naus M. Vaccine potency: the importance of maintaining the vaccine cold chain. Vaccines - children and practice. 2001;4(1):17-22.

2. Bell KN, Hogue CJR, Manning C, Kendal A. Risk factors for improper vaccine storage and handling in private office providers. Pediatrics 2001;107(6):85-89.

3. Santos BA dos, Ranieri TS, Bercini M, Schermann MT, Famer S, Mohrdieck R. An evaluation of the adverse reaction potential of three measles-mumps-rubella combination vaccines. Rev Panam Salud Publica 2002;12(4):240-246.

4. Brasil, Fundação Nacional de Saúde, Programa Nacional de Imunizações. Manual de rede de frio. 3rd ed. Brasília; FNS: 2001.

5. Brasil, Fundação Nacional de Saúde. Guia de vigilância epidemiológica. Vol. II. Brasília; FNS: 2002. 